\title{
TERAPI KOMPLEMENTER ESSENTIAL OIL LAVENDER TERHADAP PENINGKATAN DAYA TAHAN TUBUH DAN DAYA TANGKAP ANAK PRASEKOLAH
}

\author{
The Effect Of Complementary Therapy Using Lavender Essential Oil To \\ Improving Pre-School Children's Immunity And Comprehension \\ Sitti Khadijah ${ }^{1}$, Vitrianingsih ${ }^{2}$ \\ Fakultas Ilmu Kesehatan Universitas Respati Yogyakarta \\ Email : cha_midwife19@yahoo.com
}

\begin{abstract}
ABSTRAK
Latar Belakang : Anak prasekolah merupakan kelompok usia yang rentan terhadap masalah gizi dan kesehatan. Pada masa ini daya tahan tubuh anak masih belum kuat, sehingga mudah terkena penyakit infeksi. Selain itu, anak yang waktu tidurnya kurang menunjukkan kesulitan dalam konsentrasi dan aturan emosional dimana akan berpengaruh terhadap daya tangkap anak.

Tujuan : Penelitian ini bertujuan untuk menganalisis manfaat terapi komplementer essential oil lavender terhadap peningkatan daya tahan tubuh dan daya tangkap anak prasekolah di PGTK Jogja Kids Park Depok Sleman Yogyakarta.

Metode : Pengambilan data selama 2 bulan di PGTK Jogja Kids Park dengan sampel anak prasekolah (3-6 tahun). Teknik pengambilan sampel menggunakan total sampling. Jenis penelitian kuantitatif dengan rancangan analitik observasional. Desain penelitian Pre Experimental dengan One Group Pre-Post Test Design. Pre test dilakukan dengan cara observasi. Perlakuan dengan memberikan essential oil lavender selama 1 bulan menggunakan diffuser. Kemudian dilakukan post test dengan cara observasi untuk melihat kembali variabel yang diteliti. Metode pengumpulan data menggunakan lembar observasi. Analisis bivariat menggunakan uji Mc Nemar dan paired t-test.

Hasil : Hasil penelitian ada pengaruh terapi komplementer essential oil lavender terhadap peningkatan daya tangkap pada anak pra sekolah. Tidak ada pengaruh terapi komplementer essential oil lavender terhadap peningkatan daya tahan tubuh.

Simpulan : Terapi komplementer essential oil lavender dapat meningkatkan daya tangkap pada anak pra sekolah
\end{abstract}

Kata Kunci : Essential Oil, Lavender, Daya Tahan, Daya Tangkap 


\begin{abstract}
Background : Pre-school children are an age group that is vulnerable to nutrition and health problems. In this current age, children's immune system is still not strong enough so that they are susceptible to infectious diseases. Furthermore, children who have not enough sleep time show that they are difficult to concentrate and manage their emotions. Therefore, it will affect children's comprehension.

The Aim : This study aimed to analyze the benefits of complementary therapy using lavender essential oil to improving pre-school children's immunity and comprehension at PGTK Jogja Kids Park, Depok, Sleman, Yogyakarta.

Method: Data were collected for 2 months at PGTK Jogja Kids Park in which its samples were pre-school children (3 - 6 years old). The applied sampling technique was total sampling. The type of this study was quantitative research with the observational analytic model. This study was also applied preexperimental design using one group pretest-posttest design. The treatment was by giving participants the lavender essential oil using a diffuser for 1 month. Then, the posttest was conducted by observation to review the studied variables. Data were collected using observational sheets and analyzed using bivariate analysis with McNemar's test and paired t-test.

Result : The results indicated that the complementary therapy using lavender essential oil had an effect in improving pre-school children's comprehension. However, it had no effect in improving pre-school children's immunity.

Conclusion : Complemantary therapy of lavender essenntial oil can increase the ability to catch pre-school children
\end{abstract}

Keywords: Essential Oil, Lavender, Immunity, Comprehension

\title{
PENDAHULUAN
}

Anak prasekolah merupakan kelompok usia yang rentan terhadap gizi dan kesehatan. Daya tahan tubuh anak masih belum kuat, sehingga mudah terkena penyakit infeksi (Marimbi, 2010). Anak prasekolah yang waktu tidurnya kurang menunjukkan kesulitan dalam konsentrasi dan aturan emosional (Lam dkk, 2011). Sehingga tentunya juga mempengaruhi daya tangkap anak. Dalam proses pembelajaran, rangsangan yang dipakai biasanya berupa penglihatan dan pendengaran. Sistem penciuman belum banyak dipakai sebagai media dalam proses pembelajaran, khususnya yang berhubungan dengan memori jangka pendek (Hartanto, 2014).

Terapi aroma dengan essential oil digemari belakangan ini, karena masyarakat menganggap akumulasi terapi obat sintesis membawa dampak buruk pada organ tubuh seperti ginjal dan hati. Penggunaan essential oil sebagai aromaterapi dikembangkan dalam pelayanan kebidanan komplementer (Soedarsono, 2002). Aromaterapi mempunyai efek positif dimana merangsang sensori dan reseptor yang ada di hidung kemudian memberi informasi lebih jauh 
ke area di otak yang mengontrol emosi dan memori serta memberikan informasi ke hipotalamus. Hipotalamus merupakan pengatur sistem seksualitas, suhu tubuh dan reaksi terhadap stress (Koensoemardiyah, 2009). Essential oil dapat digunakan oleh anak-anak maupun dewasa, sesuai dengan teknik penggunaannya.

Salah satu essential oil yang digunakan sebagai aromaterapi yang terkenal memiliki efek menenangkan adalah lavender. Salah satu cara efektif adalah dengan inhalasi langsung, sehingga efek aromaterapi langsung bekerja (Ariyani, $\mathrm{dkk}, 2012$ ). Essential oil lavender dapat membantu menanggulangi insomnia, memperbaiki mood seseorang dan memberikan efek relaksasi (Dewi, 2013).

Berdasarkan studi pendahuluan yang dilakukan dengan metode wawancara pada guru PGTK Jogja Kids Park didapatkan bahwa daya tahan tubuh anak berbeda-beda dan sering ada anak yang tidak hadir dengan alasan sakit, ataupun hadir dengan keadaan daya tahan tubuh menurun. Saat proses pembelajaran tidak semua anak bisa berkonsentrasi sehingga kemampuan daya ingat untuk mengulang yang telah di ajarkan kurang baik.

Secara umum penelitian ini bertujuan untuk mengetahui pengaruh terapi komplementer essential oil lavender terhadap peningkatan daya tahan tubuh dan daya tangkap anak prasekolah.

\section{METODE PENELITIAN}

Jenis Penelitian yang dilaksanakan adalah penelitian kuantitatif dengan rancangan penelitian berupa analitik observasional. Desain penelitian berupa Pre Experimental berupa One Group Pre-Post Test Design dimana melakukan intervensi pada satu kelompok tanpa pembanding (Nursalam, 2011). Desain ini digunakan karena terdapat pre test dengan cara observasi langsung sebelum diberi perlakuan, hasil perlakuan dapat diketahui lebih akurat karena dapat dibandingkan dengan keadaan sebelum diberi perlakuan. Observasi yang dilakukan adalah observasi terhadap daya tahan tubuh anak dengan melihat kehadiran dan juga keadaan sehat atau sakit saat hadir. Kemudian observasi daya tangkap anak pada saat proses pembelajaran berlangsung. Perlakuan dengan memberikan essential oil lavender selama 1 bulan dengan menggunakan diffuser. Kemudian dilakukan post test dengan cara observasi untuk melihat kembali variabel yang diteliti. Essentialoil yang digunakan adalah essential oil yang sudah beredar dipasaran dan terjamin keamanannya (terdaftar BPOM). Instrumen penelitian menggunakan lembar observasi yang telah dilakukan uji validitas dan realibilitas.

Penelitian ini dilaksankan di PGTK Jogja Kids Park Depok Sleman Yogyakarta. Lokasi penelitian ini dipilih karena sangat mendukung untuk dilakukan penelitian ini dikarenakan menerapkan sistem full day school, sehingga bisa memantau pemberian terapi komplementer essential oil. Pengambilan data penelitian dilakukan selama dua bulan yaitu bulan Juli-Agustus 2019. Teknik sampling yang digunakan adalah total sampling dengan jumlah responden adalah 21 anak prasekolah. Analisa data dilakukan secara univariat dan bivariat, analisis bivariat dilakukan dengan mengggunakan uji Mc Nemar dan paired t-test

\section{HASIL DAN PEMBAHASAN}




\section{Hasil}

Berdasarkan pengumpulan data penelitian dari 21 Anak pra sekolah di PGTK Jogja Kids Park didapatkan hasil sebagai berikut:

1. Karakteristik responden

Tabel 1. Karakteristik Responden

\begin{tabular}{llcc}
\hline Variabel & & Frekuensi (N=21) & Prosentase (\%) \\
\hline Usia & 3 tahun & 7 & 33,3 \\
& 4 tahun & 4 & 19,1 \\
& 5 tahun & 8 & 38,1 \\
\multirow{3}{*}{ Jenis kelamin } & 2 & 9,5 \\
& 6 tahun & 12 & 57,2 \\
& Laki-laki & 9 & 42,8 \\
\hline
\end{tabular}

Berdasarkan tabel 1 menunjukkan bahwa sebagian besar responden berumur 5 tahun 8 anak $(38,1 \%)$ dan jenis kelamin laki-laki 12 anak $(57,2 \%)$.

2. Terapi Komplementer Essential Oil Lavender Terhadap Daya Tangkap Anak Prasekolah

Tabel 2. Terapi Komplementer Essential Oil Lavender Terhadap Daya Tangkap Anak Prasekolah

\begin{tabular}{lccccccc}
\hline Daya tangkap & Mean & N & Min & Maks & Std. Deviation & C & p-value \\
\hline Pre Test & 77,42 & 21 & 33 & 100 & 18,811 & 0,599 & 0,015 \\
Post Test & 86,47 & 21 & 52 & 100 & 15,256 & & \\
\hline
\end{tabular}

Berdasarkan hasil analisis data diperoleh kenaikan skor rerata daya tangkap anak dimana sebelum pemberian terapi komplementer essential oil lavender rerata skor 77,42 dan setelah pemberian terapi komplementer essential oil lavender naik menjadi 86,47. Berdasarkan hasil perhitungan paired t test yang disajikan didapatkan bahwa terdapat pengaruh yang signifikan terapi komplementer essential oil lavender terhadap daya tangkap anak pra sekolah dengan $p$-value $0,015<0,05$.

3. Terapi Komplementer Essential Oil Lavender dalam Peningkatan Daya Tahan Tubuh Anak Prasekolah

Tabel 3 Terapi Komplementer Essential Oil Lavender dalam Peningkatan Daya Tahan Tubuh Anak Prasekolah

\begin{tabular}{lccccc}
\hline Variabel & \multicolumn{2}{c}{ Pre Test } & \multicolumn{2}{c}{ Post Test } & \multirow{2}{*}{ p-value } \\
\cline { 2 - 5 } & $\mathbf{N}$ & $\mathbf{\%}$ & $\mathbf{N}$ & $\mathbf{\%}$ & \\
\hline Daya Tahan Tubuh & 15 & 71,4 & 18 & 85,7 & \\
$\quad$ Sehat & 6 & 28,6 & 3 & 14,3 & 0,375 \\
$\quad$ Sakit & 21 & 100 & 21 & 100 & \\
\hline Total & & &
\end{tabular}

Hasil analisis didapatkan sebelum pemberian terapi komplementer essential oil lavender daya tahan tubuh 6 anak $(28,6 \%)$ dalam kategori sakit. Kategori sakit tersebut diobservasi dalam 1 minggu terakhir. Setelah pemberian 
terapi komplementer essential oil lavender daya tahan tubuh anak dalam kategori sakit menurun menjadi 3 anak (14,3\%). Analisis bivariat didapatkan $p$-value 0,375 dimana $>0,05$ sehingga dapat disimpulkan bahwa tidak terdapat pengaruh terapi komplementer essential oil lavender terhadap daya tahan tubuh anak prasekolah

\section{Pembahasan}

Aromaterapi adalah metode yang menggunakan minyak atsiri untuk meningkatkan kesehatan fisik dan emosi. Minyak atsiri adalah minyak alami yang di ambil dari tanaman aromatik. Kandungan zat aromatik tersebut memeiliki respons yang baik tubuh (Jaelani, 2009).

Berdasarkan hasil analisis data diperoleh kenaikan skor rerata daya tangkap anak dimana sebelum pemberian terapi komplementer essential oil lavender rerata skor 77,42 dan setelah pemberian terapi komplementer essential oil lavender naik menjadi 86,47. Hasil ini dipengaruhi oleh beberapa hal, yaitu essential oil lavender dapat membuat perasaan tenang, menurunkan perasaan takut dan marah, menstabilkan emosi serta meningktakan motivasi sehingga dapat meningkatkan konsentrasi dalam mengerjakan tugas yang diberikan guru. Hal ini sesuai dengan yang diungkapkan oleh Maifrisco, bahwa aromaterapi dapat mempengaruhi bagian otak yang berkaitan dengan mood, emosi, ingatan, dan pembelajaran. Dengan menghirup aromaterapi lavender maka akan meningkatkan gelombang-gelombang alfa di dalam otak dan gelombang inilah yang membantu untuk menciptakan keadaan yang rileks (Maifrisco, 2008).

Berdasarkan hasil perhitungan paired $t$ test yang disajikan didapatkan bahwa terdapat pengaruh yang signifikan antara pemberian terapi komplementer essential oil lavender terhadap daya tangkap anak pra sekolah $(\mathrm{p}=0,015)$. Hasil penelitin ini sejalan dengan yang diungkapkan oleh Shinobi, bahwa aromaterapi mempunyai efek yang positif karena diketahui bahwa aroma tersebut dapat merangsang sensori dan reseptor yang pada akhirnya mempengaruhi organ yang lainnya sehingga dapat menimbulkan efek kuat terhadap emosi. Aroma ditangkap oleh reseptor di hidung yang kemudian memberikan informasi lebih jauh ke area di otak yang mengontrol emosi dan memori maupun memberikan informasi juga ke hipotalamus yang merupakan pengatur sistem internal tubuh, termasuk reaksi terhadap stress. Aromaterapi dapat menumbuhkan perasaan yang tenang pada jasmani, pikiran dan rohani serta mampu mememberikan rasa percaya diri dan perasaan damai (Shinobi, 2008).

Setelah diberikan essential oil dalam bentuk aromaterapi lavender selama 1 bulan terbukti dapat meningkatan daya tangkap pada anak pra sekolah. Aromaterapi dapat mempengaruhi kondisi psikis, emosi, daya ingat dan daya tangkap seseorang. Efek aromaterapi akan membuat lingkungan yang segar dan harum sehingga merangsang sensori dan akhirnya mempengaruhi organ lainnya sehingga dapat menimbulkan efek yang kuat terhadap emosi dan memori serta dan reaksi terhadap kosentrasi. Kemampuan berkonsentrasi mempengaruhi kecepatan dalam menangkap materi yang dibutuhkan. Seorang siswa yang punya kemampuan dalam berkonsentrasi akan lebih cepat dapat menangkap materi yang seharusnya ia serap (Hidayat, 2014). 
Daya tangkap seseorang dalam belajar tentu tak lepas dari konsentrasi. Konsentrasi merupakan pemusatan perhatian dalam proses perubahan tingkah laku yang dinyatakan dalam bentuk penguasaan, penggunaan, pengetahuan dan kecakapan dasar. Konsentrasi juga merupakan modal utama bagi anak dalam menerima materi ajar serta menjadi indikator suksesnya pelaksanaan pembelajaran. Menurut Ratnasari dalam Agustini \& Sudhana dalam proses belajar pada dunia pendidikan konsentrasi merupakan salah satu aspek penting untuk dapat menangkap dan menerima pelajaran. Konsentrasi dibutuhkan pada saat mendengarkan penjelasan guru, memahami materi yang diberikan, dan mengerjakan tugas (Agustini, N., \& Sudhana, H., 2014). Konsentrasi dapat terjadi apabila individu ingin menyaring secara kuat dan ingin menangkap kesan penginderaan secara lebih jelas (Hidayat, 2014).

Penggunaan terapi komplementer essential oil lavender terhadap daya tahan tubuh anak menghasilkan penurunan kategori anak yang sakit dari 6 anak $(28,65)$ menjadi 3 anak $(14,3 \%)$. Aromaterapi merupakan salah satu cara terapi dengan memanfaatkan minyak atsiri (essential oil) dan organ penciuman manusia. Sehingga berkhasiat untuk menstabilkan emosi dan perasaan, pikiran dan perasaan tenang, menjadikan penghirup dapat menghadapi situasi cemas dengan tenang (Kasanah, 2005).

Efek wewangian esensial pada tubuh dan pikiran dapat menghilangkan stress, meningkatkan kekebalan tubuh dan menimbulkan perasaan bugar (Kaina, 2006). Aromaterapi lavender dapat meningkatkan sistem kekebalan tubuh (Howard, 2007). Namun tidak sesuai dengan hasil analisis bivariat dimana didapatkan $p$-value 0,375 dimana $>0,05$ sehingga dapat disimpulkan bahwa tidak terdapat pengaruh pemberian terapi komplementer essential oil lavender terhadap daya tahan tubuh anak prasekolah.

\section{Simpulan}

\section{SIMPULAN DAN SARAN}

Rerata skor daya tangkap anak sebelum pemberian terapi komplementer essential oil lavender yaitu 77,42 dan terjadi kenaikan setelah pemberian terapi komplementer sebesar 9,05 yaitu menjadi 86,47. Ada pengaruh penggunaan essential oil lavender terhadap daya tangkap pada anak pra sekolah dengan pvalue $0,015<0,05$. Tidak ada pengaruh penggunaan essential oil lavender terhadap daya tahan tubuh pada anak pra sekolah dengan p-value 0,375 $>0,05$

\section{Saran}

Bagi orang tua dan guru, pemberian terapi komplementer berupa essential oil lavender dapat dijadikan sebagai salah satu alternatif yang dapat dilakukan untuk meningkatkan daya tangkap pada anak pra sekolah. Bagi Bidan dapat memberikan sosialisasi dan edukasi kepada masyarakat terkait adanya terapi komplementer khususnya essential oil lavender sebagai salah satu alternatif penanganan masalah daya tangkap pada anak pra sekolah. Bagi peneliti selanjutnya dapat dilakukan penelitian serupa dengan mengganti essential oil lavender dengan jenis aromaterapi lain serta memodifikasi durasi dan konsentrasi essensial oil yang digunakan. 


\section{DAFTAR PUSTAKA}

Agustini, N., \& Sudhana, H. (2014). Pengaruh Pemberian Aromaterapi Terhadap Konsentrasi Siswa Kelas V Sekolah Dasar dalam Mengerjakan Soal Ulangan Umum. Jurnal Psikologi Udayana. Vol 1 (2): 271-278.

Ariyani, N,W,N., Yunianti, Ni Luh Putu., Adriana, D. (2012). Pengaruh Pemberian Aromaterapi Cendana terhada Kualitas Tidur Remaja di Panti Asuhan Dharma Jati II Denpasar. Diunduh tanggal 2 Agustus 2018.

Dewi, I. P. (2013). Aromaterapi Lavender sebagai media relaksasi. Bagian Farmasi Fakultas Kedokteran Universitas Udayana. Dari http://ojs.unud.ac.id/index.php/eum/article/viewFile/4871/3657 Diunduh tanggal 2 Agustus 2018.

Hartanto, M.M. (2014). Pengaruh Aromaterapi Sandalwood terhadap Fungsi Memori Jangka Pendek. Jurnal Media Medika Muda. Universitas Diponegoro Semarang.

Hidayat, S. (2014). Pengaruh Msuik Kelasik Terhadap Daya Tahan Konsentrasi Dalam Belajar. Skripsi. Universitas Islam Negeri Sultan Syarif Kasim.

Howard S, Hughes BM Expectancies. (2007). Not aroma, explain impact of lavender aromatherapy. New England Journal of Medicine. Journal of Health Psychology (2008), 13, 603-617.

Jaelani. (2009). Aromaterapi. Jakarta : Pustaka Populer Obor.

Kaina. (2006). Aromaterapi. Grafindo Litera Media : Yogyakarta.

Kasanah, Noer. (2005). Aromaterapi. http://imsasisters.imsa.us/index.php?option $=$ com content\&task $=$ view\&id $=135 \&$ Item $\underline{\mathrm{id}=99}$ ) diakses tanggal 3 November 2019.

Koensoemardiyah. (2009). A-Z Aromaterapi untuk Kesehatan, Kebugaran dan Kecantikan. Yogyakarta : Lily Publisher.

Lam, J.C., Mahone, E., Mark., Mason., Thornton and Schart, S.M. (2011). The Effect of Napping on Cognitive Function in Preschoolers. USA : PudMed. Go. Diunduh dari http://www.ncbi.nlm.nih.gov/pmc/articles/PMC3095909/ tanggal 2 Agustus 2018.

Maifrisco, O. (2008). Pengaruh Aromaterapi Terhadap Tingkat Stres Mahasiswa. (online). $\quad$ http://www.aroma.com/doc/22355491/PengaruhAromaterapiTerhadap-Tingkat-StresMahasiswa diakses 03 November 2019.

Marimbi, H. (2010). Tumbuh Kembang, Status Gizi dan Imunisasi Dasar pada Balita. Yogyakarta : Nuha Medika.

Nursalam. (2011). Konsep dan Penerapan Metodologi Penelitian Ilmu Keperawatan. Jakarta : Salemba Medika.

Shinobi. (2008). Pijat aromaterapi. Available from URL: http://id.88db.com/id/Discussion/Discussion_reply.page/Health_Medical/? DicID=1309 [Accessed 03 November 2019].

Soedarsono. (2002). Tumbuhan Obat. Yogyakarta : Pusat Penelitian Obat Tradisional Universitas Gadjah Mada. 